\title{
Interspecific Differences in the Metabolic Rate, Gill Dimension and Hematology of Fish in an Amazonian Floodplain Lake
}

\begin{abstract}
Wallice P. Duncan
Laboratório de Morfologia Funcional, Universidade Federal do Amazonas. Avenida Rodrigo Otavio, 6200. Coroado I, 69.080-900, Manaus AM, Brasil. E-mail: wduncan@ufam.edu.br
\end{abstract}

Received: December 4, 2019 Accepted: February 10, 2020 Published: February 24, 2020

doi:10.5296/ast.v8i1.15981

URL: https://doi.org/10.5296/ast.v8i1.15981

\begin{abstract}
It has been hypothesized that respiratory physiology in fish is closely associated with ecological traits. Therefore, data on gill morphometrics (lamellae frequency, gill surface area and barrier thickness), metabolic rate (oxygen consumption) and blood oxygen capacity (hematology) were analyzed in several fish, including benthic, bentho-pelagic and pelagic species collected in an Amazon floodplain lake. Similar to other teleostean species, the 2nd and 3rd gill arches have numerous large filaments in both pelagic and benthic species, as these characteristics tend to increase the gill surface area. A large gill area (4 to $7 \mathrm{~cm}^{2} \mathrm{~g}^{-1}$, mass-specific) is associated with a high (100 to $300 \mathrm{mg} \mathrm{O} \mathrm{h}^{-1} \mathrm{~kg}^{-1}$ ) routine oxygen consumption rate and has been observed in active pelagic swimmers, such as Cichla monoculus and Pygocentrus nattereri. Benthic dwelling fish (e.g., Pterygoplichthys pardalis and Sorubim lima) have low metabolic rates (20 to $50 \mathrm{mg} \mathrm{O}_{2} \mathrm{~h}^{-1} \mathrm{~kg}^{-1}$ ), small gill dimensions (2 to $3 \mathrm{~cm}^{2} \mathrm{~g}^{-1}$, mass-specific), low hemoglobin levels ( 3 to $5 \mathrm{~g} \mathrm{dL}^{-1}$ ), reduced numbers of circulating red blood cells ( 1 to $2 \times 10^{6} \mathrm{~mm}^{-3}$ ) and low hematocrit values (25 to $35 \%$ ) compared to pelagic species. These results demonstrated that pelagic fish have high routine oxygen consumption rates compatible with their large gill surface area and high blood oxygen capacity, whereas benthic species have low metabolic rates, small gill dimensions and reduced blood oxygen capacity.
\end{abstract}

Keywords: benthic fish, pelagic fish, gill area, oxygen uptake, blood parameters

\section{Introduction}

It has been suggested that pelagic fish are generally more active than benthic species (Roberts 1975; Jonhston et al. 1988). The high energy demand in pelagic fish is attributable to active swimming, which is in contrast with the sluggish behavior of benthic species (Childress 1995; Killen et al. 2010). Thus, it is expected that active fish have (i) a high gill surface area to 
enable more effective oxygen uptake in supplying their high-energy demand (Wegner et al. 2010); (ii) high oxygen consumption rates (as indirect indicator of metabolic rates) to yield aerobic ATP (Val \& Almeida-Val 1995); (iii) a high blood oxygen capacity to carry oxygen through the blood (Nikinmaa \& Soivio 2005); and (iv) adjusted functional integration between gill area, oxygen consumption rates and hematological profile (Weibel 2000). In other words, the routine oxygen rate is a function of the gill surface area, assuming that all extracted oxygen from the gill epithelium is carried through the blood.

The species-specific anatomy and dimensions of the gills often reflect the performance of the fish under various environmental conditions (Ong et al. 2007; Matey et al. 2011). The measurement of respiratory area is based on the number and length of the filaments, surface area of lamellae and spacing of the lamellae along the filaments (Hughes \& Morgan 1973). These authors have extensively described the relationship between the gill dimensions and lifestyle of several fish species. In addition, it has been reported that variations are correlated with high tolerances to hypoxia or notably high energy demand (De Jager \& Dekker 1975). It has been argued that gill dimensions appear to be closely matched to the requirement for oxygen (Nilsson \& Östlund-Nilsson 2008; Wegner et al. 2010). Thus, it is expected that gill surface area has a linear relationship with oxygen uptake (Rogers et al. 2016). In addition, the diffusion distance between blood and water is an important variable linking branchial morphology to the capacity for oxygen consumption (Hughes 1984, Hughes et al. 1986).

If the gill structures are matched to oxygen uptake in water, it is expected that blood oxygen carrying capacity is also adjusted to metabolic rate. The oxygen transport in the blood may depend directly on (i) the number of circulating red blood cells and hemoglobin concentration and (ii) the functional properties of hemoglobin and its allosteric modulators (Nikinmaa \& Soivio 2005; Brunori 2014). It has been reported that active swimming fish have more circulating red cell blood and high hemoglobin levels, while sluggish fish and/or those living in low oxygen environments tend to have the functional properties of hemoglobin modulated by a high affinity for oxygen (Powers 1980; Wells 2009; Brunori 2014). Considering all the arguments outlined above, there is support for the concept of symmorphosis, which is the capacity of structural elements to match but not exceed the functional requirements of an animal (Weibel 2000). This hypothesis was tested initially in the mammalian respiratory system (Weibel et al. 1991) and is expected to have similar effects on fish respiration (Rombough \& Moroz 1997), considering that gill area and oxygen consumption rate increase according to fish growth (Pauly 1981, Hughes et al. 1986). At present, it is not clear whether gill area, oxygen consumption rate, and blood oxygen capacities are closely matched in the Amazon teleostean species, since these fish employ different mechanisms to tolerate hypoxia.

Several biochemical, physiological, behavioral and morphological adaptations to survival in low oxygen concentrations have been reported in many Amazon fish species (Val \& Almeida-Val 1995; Campos et al. 2016). A survey of tolerance to hypoxia in Amazon fish indicated large degrees of variation among and within some species. Some cichlids possess a specialized metabolism to survive hypoxia or even anoxia (Muusze et al. 1998, Chippari-Gomes et al. 2005, De Boeck et al. 2013). Several species increase opercular movements to increase oxygen uptake when concentrations decrease to $1 \mathrm{mg} \mathrm{L}^{-1}$ (Saint-Paul 
\& Soares 1987). Characins, such as Colossoma macropomum Cuvier (1816), have hemoglobin with a great affinity for oxygen (Saint-Paul 1984), while several species display aquatic surface respiration when the dissolved oxygen reaches $0.5 \mathrm{mg} \mathrm{L}^{-1}$ (Saint-Paul \& Soares 1987). Considering this background information, the present study examines the relationship between routine oxygen consumption rates, gill area and blood oxygen-carrying capacity in fish from a floodplain lake in the Central Amazon. In addition, we tested the hypothesis of whether pelagic active swimming fish have higher metabolic rates than benthic sluggish fish.

\section{Materials and Methods}

\subsection{Study Area and Fish}

Lake Janauacá is located in the municipality of Careiro Castanho $\left(03^{\circ} 23^{\prime} \mathrm{S} ; 63^{\circ} 12^{\prime} \mathrm{W}\right)$ approximately $40 \mathrm{~km}$ from Manaus city (Fig. 1). This lake is typically muddy-type water covering approximately $18 \mathrm{~km}^{2}$ of flooded area. The lake is connected with the Solimões/Amazon River through a small canal $12 \mathrm{~km}$ long. In this study, fish collections were performed at this small canal. The limnological variables of the lake are strongly influenced by the main canal of the Solimões River. This river is also classified as white-type water (muddy) with high total values of dissolved particles $\left(\sim 90 \mathrm{mg} \mathrm{L}^{-1}\right)$ and electrical conductivity (60-75 $\mu \mathrm{S} \mathrm{cm}^{-1}$ ) and circumneutral $\mathrm{pH}$ (6-7). All variables were measured with a handheld multiparameter water quality meter (Consort C535 multiparameter, Consort bvba, Turnhout, Belgium).

During the field study in October 2013, the water level in the river decreased. Fish were caught with four different sizes of gillnets (24-60 mm mesh). The nets were maintained at different water depths to sample both benthic and pelagic (and bentho-pelagic) fish during each hour of collection. The healthy fish without signs of injury or diseases were immediately placed in tanks (1,000 liters) supplied with water from a location near to where the fish were collected. The physical and chemical characteristics of the water used in the experiments were as follows: $\mathrm{pH}(6.6 \pm 0.4)$, conductivity $\left(91.6 \pm 4.1 \mu \mathrm{S} \mathrm{cm}^{-1}\right)$, total dissolved solids $\left(48.8 \pm 3.7 \mathrm{mg} \mathrm{L}^{-1}\right)$, dissolved oxygen $\left(4.5 \pm 0.7 \mathrm{mg} \mathrm{O}_{2} \mathrm{~L}^{-1}\right)$, temperature $\left(27.5 \pm 0.8{ }^{\circ} \mathrm{C}\right), \mathrm{Na}^{+}$ $(135 \pm 11.8 \mu \mathrm{M}), \mathrm{K}^{+}(16.6 \pm 2.1 \mu \mathrm{M})$, and $\mathrm{Ca}^{+2}(176.2 \pm 21.9 \mu \mathrm{M})$. Conductivity, dissolved solids, dissolved oxygen and temperature were measured using a Consort C535 multiparameter analyzer (CONSORT bvba, Turnhout, Belgium), while $\mathrm{Na}^{+}, \mathrm{K}^{+}$and $\mathrm{Ca}^{2+}$ levels were analyzed by flame photometry (Digimed DM-62, Campo Grande, Brazil).

To examine the relationship between routine oxygen consumption rates, blood oxygen capacity and gill dimensions, the following fish were studied: Pinirampus pirinampu Spix \& Agassiz, 1829 ( $\mathrm{n}=8)$, Pterygoplichthys pardalis Castelnau, $1855(\mathrm{~N}=8)$, Hemisorubim platyrhynchos Valenciennes, $1840(\mathrm{n}=8)$, Sorubim lima Bloch \& Schneider, $1801(\mathrm{n}=10)$, Ageneiosus ucayalensis Castelnau, $1855(\mathrm{n}=9)$, Pygocentrus nattereri Kner, $1858(\mathrm{~N}=7)$, Mylossoma duriventre Cuvier, $1818(\mathrm{~N}=8)$, Psectrogaster amazonica Eigenmann \& Eigenmann, $1889(\mathrm{n}=8)$, Astronotus ocellatus Agassiz, $1831(\mathrm{n}=9)$ and Cichla monoculus Agassiz, $1831(\mathrm{n}=7)$. One individual of each species was included as a voucher specimen in the fish collection at the Laboratory of Functional Morphology, Federal University of 
Amazonas (Manaus, Brazil). All procedures followed the Brazilian animal welfare standards (Ethical Committee of Animal Experimentation, CEUA/UFAM protocol No 014/2014).
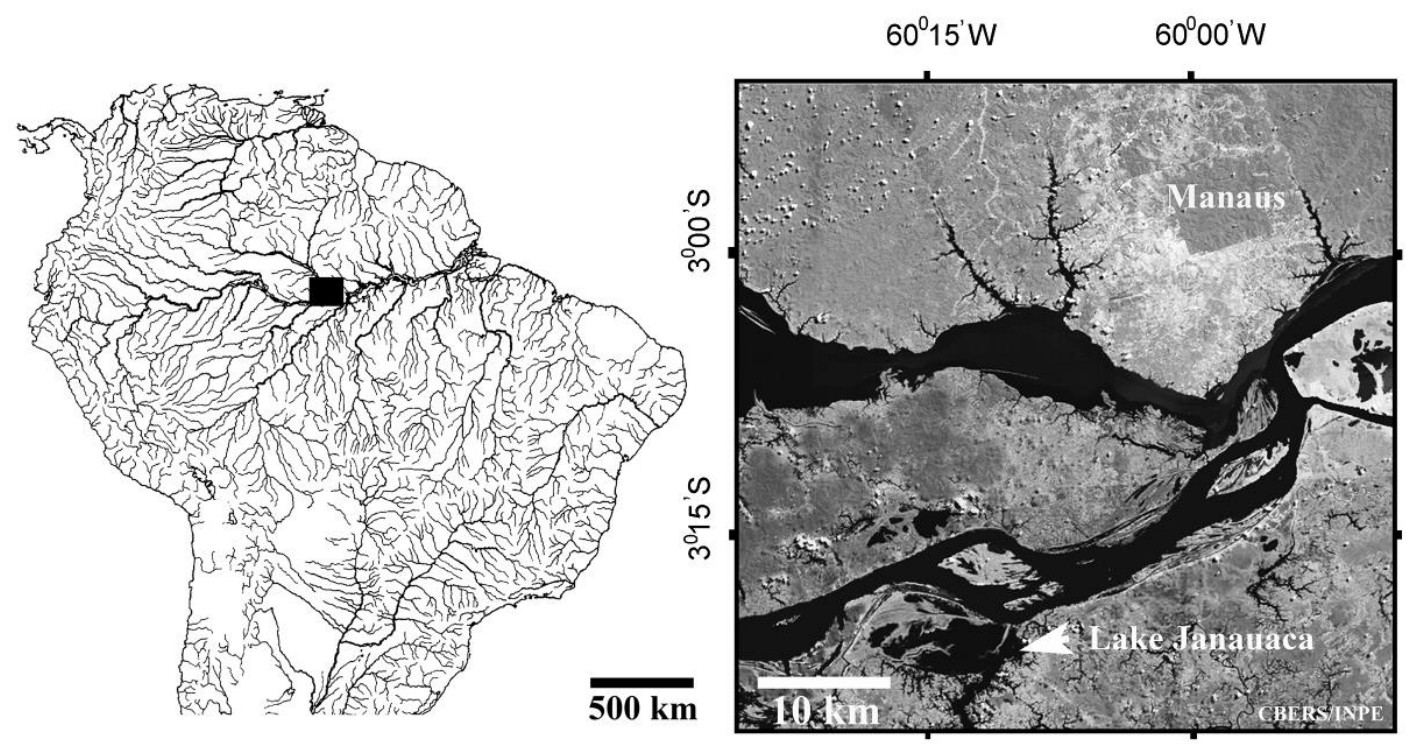

Figure 1. Map of the study site indicating Lake Janauacá (a floodplain lake in the Central Amazon) near Manaus city ( 40 km)

\subsection{Routine Oxygen Consumption Rate and Opercular Movement Measurements}

Fish were kept in their native water 24 hours prior to initiating the experiments. The routine oxygen consumption rate (as indirectly measured by the routine metabolic rate) and opercular beat frequency were measured. To estimate the metabolic rate, a closed respirometric system was built. A Clark electrode was coupled to a rectangular chamber (10 liters), and oxygen content was monitored with an oxygen probe sensor (SZ10T, Consort C535 multiparameter, Consort bvba, Turnhout, Belgium). Individual fish were placed into the chamber and allowed to acclimate for $30 \mathrm{~min}$. The water oxygen content was adjusted to approximately $5 \mathrm{mg} \mathrm{L}^{-1}$ by air pumps. The air supply was later turned off, and the system was closed to monitor the routine oxygen consumption rate through fish respiration for $20 \mathrm{~min}$ at an environmental temperature $\left(\sim 27{ }^{\circ} \mathrm{C}\right)$. To avoid sources of variation in the oxygen consumption measurements due to progressive hypoxia and hypercapnia, the $\mathrm{O}_{2}$ concentration in the chamber was not below $\sim 2 \mathrm{mg} \mathrm{L}^{-1}$. The oxygen uptake rate was calculated as $\mathrm{MO}_{2}=(\triangle \mathrm{mg}$ $\mathrm{O}_{2}$ h-1) x $V_{\text {resp }} M$, where $\triangle \mathrm{mg} \mathrm{O}_{2} \mathrm{~h}-1$ is the change in ambient oxygen content over time, $V_{\text {resp }}$ is the respirometer volume and $M$ is the fish mass. The opercular movement was determined by direct count of operculum beating for $1 \mathrm{~min}$ over 10-min intervals. The measurements were performed 3 times and expressed as the number of opercular beats $\min ^{-1}$.

\subsection{Blood Sampling and Hematological Analyses}

After the respirometric study, the fish were kept in their native water for 2 hours to recover. Fish were euthanized with an overdose of benzocaine $\left(0.8 \mathrm{~g} \mathrm{~L}^{-1}\right)$, and blood was sampled from the caudal vessel using a heparinized syringe to avoid hemocoagulation. Samples were kept on ice until analysis in hematological studies. The following variables of blood structure 
were obtained: hematocrit, concentration of hemoglobin and circulating red blood cell count. Hematocrit was measured by collecting blood in microheterocrit tubes and then centrifuging for $10 \mathrm{~min}$ at $10,000 \mathrm{rpm}$, immediately followed by hematocrit measurements. The hemoglobin concentration was measured by the cyanmethemoglobin method: $10 \mu \mathrm{L}$ of blood was placed into $2 \mathrm{~mL}$ of Drabkin's solution and gently mixed by inversion, and the absorbance was measured at $546 \mathrm{~nm}$ using a microplate Multiskan ${ }^{\mathrm{TM}}$ Go Spectrophotomer (Thermo Scientific, Waltham, MA, USA). The hemoglobin concentration is reported as $\mathrm{g} \mathrm{dL}^{-1}$. The number of circulating red blood cells (erythrocytes $\times 10^{6} \mu \mathrm{L}^{-1}$ ) was determined by transferring $10 \mu \mathrm{L}$ of blood (well-mixed) into $2 \mathrm{~mL}$ of formalin-citrate buffer solution. The red blood cells were counted using a Neubauer chamber under a light microscope at 400x. The following erythrocyte indices were calculated: mean corpuscular hemoglobin (hemoglobin x 10/red blood cell count), mean corpuscular hemoglobin concentration (hemoglobin x 100/hematocrit) and mean corpuscular volume (hematocrit x 10/red blood cell count).

\subsection{Light and Scanning Electron Microscopy}

Gill samples were dehydrated through a graded ethanol series and embedded in methacrylate (Historesin, Leica, Heidelberg, Germany). The tissue was sectioned at $3 \mu \mathrm{m}$ sagittally using a Slee Medical GmbH microtome (model CUT 5062, Mainz, Germany) and stained with toluidine blue $(0.13 \%)$. Digital images were acquired using a Carl Zeiss camera (Axiocam ERc5s Göttingen, Germany) mounted on a Carl Zeiss light microscope (Primo Star) and analyzed using NIH ImageJ 1.45s computer software (Wayne Rasband. National Institute of Mental Health, Bethesda, USA) to determine the lamellar frequency and water-blood barrier (magnified at 1,000x). The thickness of the water-blood barrier was estimated using a test line of a semicircular grid (Merz's grid), as described by Hughes et al. (1986). For each animal, the barrier thickness was calculated as $2 / 3$ of the harmonic mean length. The anatomical diffusion factor of the water-blood barrier was estimated as the quotient of the mass-specific respiratory surface area $\left(S_{\text {gill }} / \mathrm{M}_{b}\right)$ and $2 / 3$ of the harmonic mean of diffusion barrier thickness. To estimate the bilateral lamellar area, gill samples were processed for scanning electron microscopy procedures. Intact secondary lamellae of each animal were dehydrated using a graded ethanol series followed by immersion in 1,1,1,3,3,3-hexamethyl-disilazane (Sigma Co., Steinheim, Germany), and air-dried. The filaments were coated with gold (99\%) and examined under an FEI Quanta 250 scanning electron microscope at $25 \mathrm{kV}$. The digital images acquired (magnified at 500x) of the lamellae were analyzed to estimate the lamellar area.

\subsection{Gill Morphometrics}

The four gill arches were immediately removed and fixed by immersion in $2.5 \%$ phosphate-buffered glutaraldehyde solution, $\mathrm{pH}$ 7.4. The gill surface area of each individual arch was estimated using the method established by Hughes (1984) and calculated by the

equation $S_{\text {gill }}=$ LTF.$F_{\text {lam }} \cdot S_{\text {lam }}$, where $S_{\text {gill }}$ is the total surface area, LTF is the total length 
of the gill filaments, $F_{\text {lam }}$ is lamellar frequency (for both sides of each filament) and $S_{\text {lam }}$ is the mean bilateral surface area of the average secondary lamella. All filaments on the four gill arches of each hemibranch were counted. The length of every $10^{\text {th }}$ filament was estimated, including the first and last filaments. Total filament length was calculated as the product of the mean filament length and total number of counted filaments, multiplied by two to account for both sides of the animal.

\subsection{Statistical Analysis}

All data are expressed as the means \pm standard errors. Principal component analysis (PCA) was applied to the correlation matrix (Pearson) formed by the $\log (\mathrm{x}+1)$-transformed data of gill morphometrics, routine oxygen consumption rate and opercular movement. Similar procedures were performed with hematological data. The principal component axes retained for interpretation were those with eigenvalues larger than 1.0. Linear regression was used to verify the relationship between gill morphometrics, routine oxygen consumption rate, opercular movement and hematological data. The uniformity of the data was tested using the Kolmogorov-Smirnov test. Comparisons of physiological variables among fish species were made with the Kruskal-Wallis nonparametric ANOVA test. The comparisons with routine metabolic rate and gill surface area were made with mass-specific adjusted values. Alternatively, predicted values of routine metabolic rate (RMR) measurements of all ten species were generated by the equation $\mathrm{RMR}=1.55 \mathrm{M}^{0.64}$ for a neotropical characin, Colossoma macropomum, at $30^{\circ} \mathrm{C}$ (Saint-Paul 1983). The PCA ordination diagrams and statistics were performed using PAST software (http://folk.uio.no/ohammer/past), while the linear regressions and the graphics were performed by using SigmaPlot ${ }^{\mathrm{TM}}$ version 11 (Systat Software, Inc., San Jose, California, USA) at the 5\% level of significance.

\section{Results}

\subsection{Routine Oxygen Consumption (RMR) and Opercular Breathing Frequency}

With the exception of Astronotus ocellatus, pelagic fish such as Pygocentrus nattereri, Mylossoma duriventre, Psectrogaster amazonica and Cichla monoculus have high values of mass-specific metabolic rates compared to benthic/bentho-pelagic species, such as Pterygoplichthys pardalis, Hemisorubim platyrhynchos, Sorubim lima and Ageneiosus ucayalensis (Fig. 2A). As a pelagic predator, C. monoculus has a resting metabolic rate 5-fold greater than that of Pinirampus pirinampu, the most active benthic fish already studied over the years. However, using values predicted by equation RMR $=1.55 M^{0.64}$ (Saint-Paul 1983), this difference was only 1.5 -fold. In addition, the predicted RMR values show notably similar results among species (Table 1).

The oxygen consumption measurement was not associated with opercular movement. For example, S. lima had an opercular frequency of 166 beats/min and an RMR of $<20 \mathrm{mg} \mathrm{O}_{2} \mathrm{~h}^{-1}$ $\mathrm{kg}^{-1}$, while A. ucayalensis had an opercular frequency of 130 beats/min and an RMR $>40 \mathrm{mg}$ $\mathrm{O}_{2} \mathrm{~h}^{-1} \mathrm{~kg}^{-1}$ (Fig. 2B). 


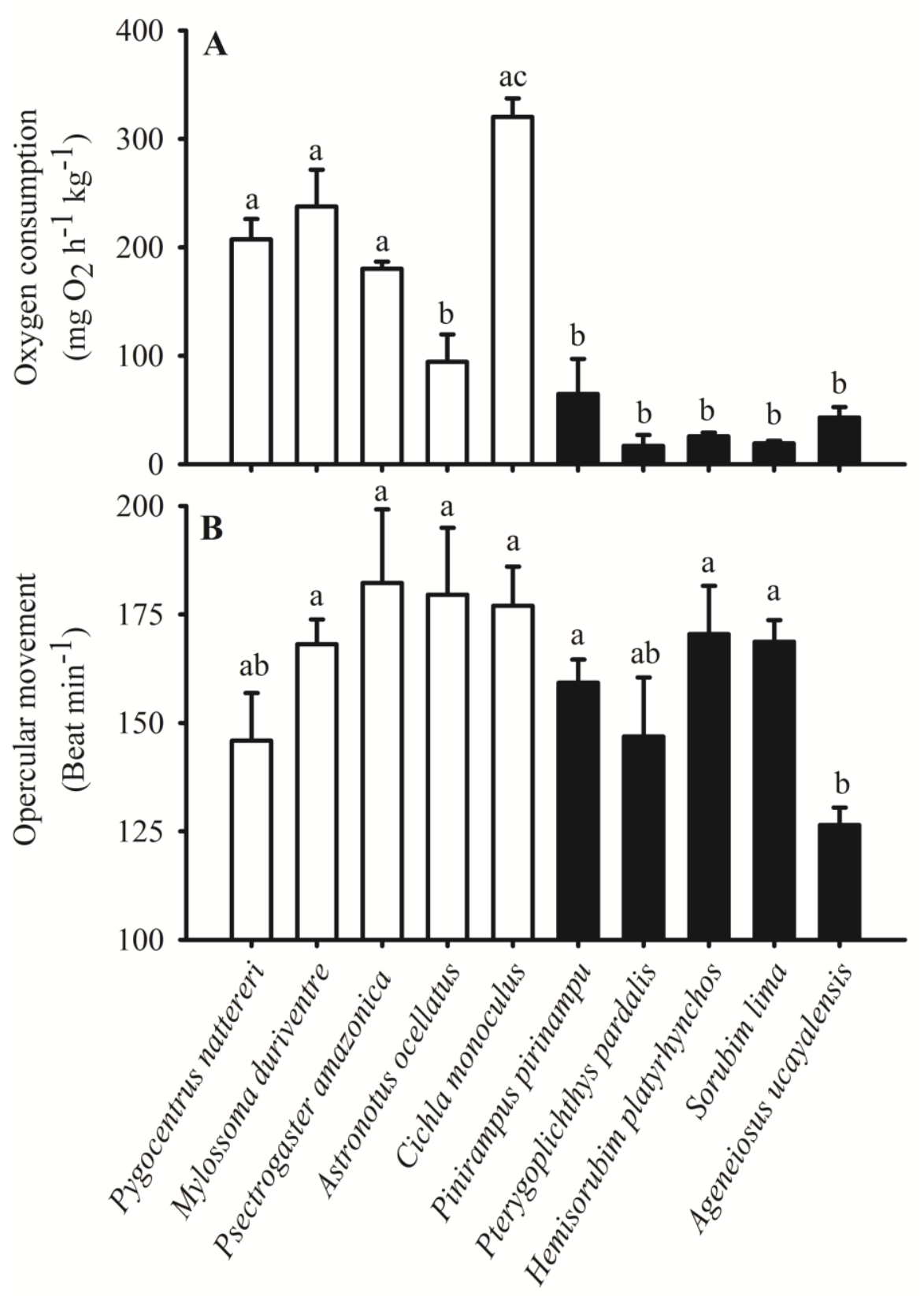

Figure 2. Interspecific variations in oxygen consumption rate (A) and opercular movement (B) in several fish species analyzed from Lake Janauacá. The routine metabolic rate (as oxygen consumption, $\mathrm{mg} \mathrm{O}_{2} \mathrm{~h}-1 \mathrm{~kg}-1$ ) was measured in a closed respirometer at $\sim 27^{\circ} \mathrm{C}$. The open bars represent the pelagic species, and the filled bars represent benthic/bentho-pelagic species. Different lowercase letters indicate significant differences among the species $(p<0.05)$ by Kruskal-Wallis nonparametric ANOVA multiple comparisons test 


\section{I Macrothink}

Table 1. Routine oxygen consumption rate (RMR per fish) in different fish species from a floodplain lake (Lake Janauacá). (\$) Predicted RMR per fish was calculated according to the equation $\mathrm{RMR}=1.55 M^{0.64}$. The relationship between RMR and body mass has previously been reported by Saint-Paul (1983) for neotropical characin, Colossoma macropomum, at $30^{\circ} \mathrm{C}$

\begin{tabular}{|c|c|c|c|c|}
\hline & Species & $\begin{array}{l}\text { Mass } \\
(\mathrm{g})\end{array}$ & $\begin{array}{c}\text { RMR } \\
\left(\mathrm{mg} \mathrm{O}_{2} \mathrm{~h}^{-1}\right. \\
\text { per fish) }\end{array}$ & $\begin{array}{c}\text { Predicted } \\
\text { RMR } \\
\left(\mathrm{mg} \mathrm{O}_{2}\right. \\
\left.\mathrm{h}^{-1}\right) \ddagger\end{array}$ \\
\hline \multirow{5}{*}{ Pelagic species } & Pygocentrus nattereri & $167.5 \pm 10.4$ & $34.7 \pm 9.2$ & 41.1 \\
\hline & Mylossoma duriventre & $149.5 \pm 9.5$ & $34.9 \pm 11.3$ & 38.2 \\
\hline & $\begin{array}{l}\text { Psectrogaster } \\
\text { amazonica }\end{array}$ & $196.2 \pm 11.7$ & $36.0 \pm 12.1$ & 45.5 \\
\hline & Astronotus ocellatus & $67.3 \pm 4.1$ & $6.3 \pm 2.4$ & 22.9 \\
\hline & Cichla monoculus & $571.4 \pm 48.6$ & $182.8 \pm 35.6$ & 90.1 \\
\hline \multirow{5}{*}{$\begin{array}{l}\text { Benthic/ } \\
\text { Bentho-pelagic } \\
\text { species }\end{array}$} & Pinirampus pirinampu & $312.9 \pm 13.8$ & $18.3 \pm 3.8$ & 61.3 \\
\hline & $\begin{array}{l}\text { Pterygoplichthys } \\
\text { pardalis }\end{array}$ & $151.7 \pm 12.2$ & $2.0 \pm 1.2$ & 38.6 \\
\hline & $\begin{array}{l}\text { Hemisorubim } \\
\text { platyrhynchos }\end{array}$ & $198.8 \pm 10.0$ & $5.0 \pm 1.3$ & 45.8 \\
\hline & Sorubim lima & $237.0 \pm 17.7$ & $4.4 \pm 1.3$ & 51.3 \\
\hline & $\begin{array}{l}\text { Ageneiosus } \\
\text { ucayalensis }\end{array}$ & $241.3 \pm 19.4$ & $10.8 \pm 2.9$ & 51.9 \\
\hline
\end{tabular}

\subsection{Gill Dimensions}

The average values for gill measurements are shown in Table 1. With the exception of $M$. duriventre and A. ocellatus, pelagic species (e.g., P. nattereri, P. amazonica and C. monoculus) have a lamellae density (40-66 lamellae $\mathrm{mm}^{-1}$ ) greater than benthic fish (18-24 lamellae $\mathrm{mm}^{-1}$ ). On the other hand, benthic and pelagic fish have similar lamellar areas. Therefore, a larger lamellar area is not enough to increase both the total respiratory gill surface (Table 2) and mass-specific gill area (Fig. 3A). For example, H. platyrhynchos has a lamellar area 1.6 


\section{Macrothink}

times greater than that of $P$. amazonica. However, this characin presents more lamellae per millimeter of filament than does catfish. Thus, the gill surface area estimated in catfish is twice as large, although the fish have the same size (Table 2). The water-blood barrier to gas exchange is highly variable and is not associated with either pelagic or benthic environments. Some species, such as $C$. monoculus and $P$. pirinampu, have a diffusion barrier significantly thicker than the other species. On the other hand, the anatomical diffusion factor (a ratio between mass-specific gill area and diffusion barrier) was higher (Fig. 3B) in pelagic fish (0.9-3.3 $\left.\mathrm{cm}^{2} \mathrm{~g}^{-1} \mu \mathrm{m}^{-1}\right)$ than in benthic fish $\left(0.6-1.1 \mathrm{~cm}^{2} \mathrm{~g}^{-1} \mu \mathrm{m}^{-1}\right)$. Analysis of the secondary lamellae from each arch, regardless of lifestyle, indicates that the $2^{\text {nd }}$ and $3^{\text {rd }}$ gill arches possess larger surface areas than the other arches. In general, the gill arches of benthic fish have smaller surface areas than pelagic fish (Table 3 ).

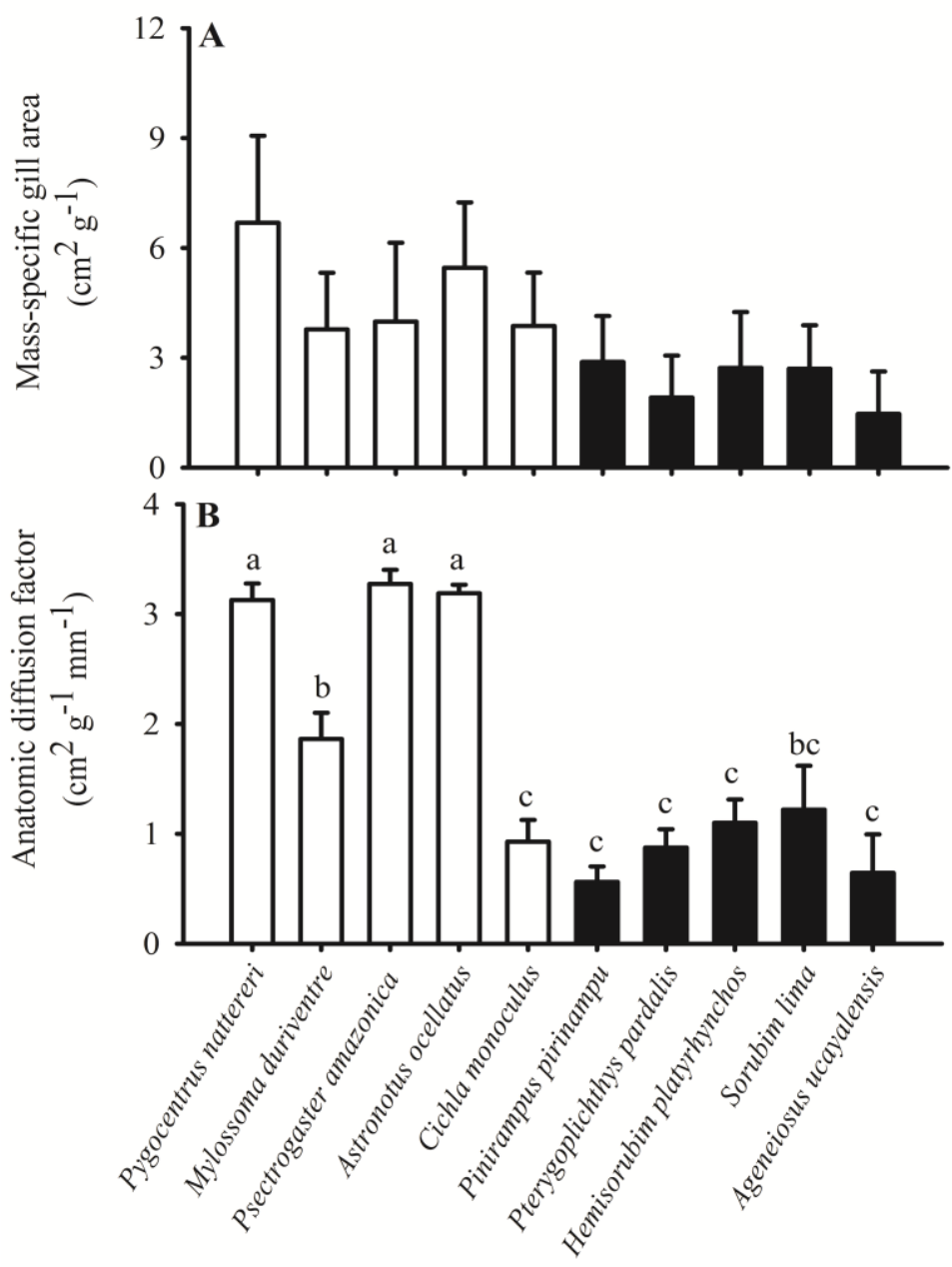

Figure 3. Mass-specific gill area (A) and anatomical diffusion factor (ADF) (B) among fish species collected from Lake Janauacá. The open bars represent the pelagic species, and the filled bars represent benthic/bentho-pelagic species. Different lowercase letters indicate significant differences among the species $(\mathrm{p}<0.05)$ by Kruskal-Wallis nonparametric ANOVA multiple comparisons test 


\section{Macrothink}

Aquatic Science and Technology

ISSN 2168-9148

2020, Vol. 8, No. 1

Table 2. Gill dimensions in different fish species from a floodplain lake (Lake Janauacá).

Different lowercase letters indicate significant differences among the species $(\mathrm{p}<0.05)$ by

Kruskal-Wallis nonparametric ANOVA multiple comparisons test. Lamellae area and total gill area were not tested due to size-dependent effects

\begin{tabular}{|c|c|c|c|c|c|}
\hline & Species & $\begin{array}{l}\text { Lamellae } \\
\text { frequency } \\
(\text { number } \\
\left.\mathrm{mm}^{-1}\right)\end{array}$ & $\begin{array}{c}\text { Lamellae } \\
\text { area } \\
\left(\mathrm{x} 10^{-3}\right. \\
\left.\mathrm{mm}^{2}\right)\end{array}$ & $\begin{array}{c}\text { Barrier } \\
\text { thickness } \\
2 / 3 \\
\text { harmonic } \\
\text { mean }(\mu \mathrm{m})\end{array}$ & $\begin{array}{l}\text { Total gill } \\
\text { area }^{\dagger} \\
\left(\mathrm{cm}^{2}\right)^{*}\end{array}$ \\
\hline \multirow{5}{*}{ Pelagic species } & $\begin{array}{l}\text { Pygocentrus } \\
\text { nattereri }\end{array}$ & $66.7 \pm 3.1^{\mathrm{a}}$ & $91.6 \pm 2.3$ & $2.1 \pm 0.3^{\mathrm{a}}$ & $1094.4 \pm 42.8$ \\
\hline & $\begin{array}{l}\text { Mylossoma } \\
\text { duriventre }\end{array}$ & $31.4 \pm 1.8^{\mathrm{b}}$ & $107.1 \pm 8.4$ & $1.4 \pm 0.2^{b}$ & $360.7 \pm 22.6$ \\
\hline & $\begin{array}{l}\text { Psectrogaster } \\
\text { amazonica }\end{array}$ & $40.6 \pm 2.2^{c}$ & $77.6 \pm 6.5$ & $1.3 \pm 0.2^{b}$ & $876.4 \pm 54.1$ \\
\hline & Astronotus ocellatus & $24.0 \pm 1.3^{\mathrm{b}}$ & $100.1 \pm 7.2$ & $1.2 \pm 0.2^{b}$ & $266.3 \pm 21.7$ \\
\hline & Cichla monoculus & $44.6 \pm 4.4^{\mathrm{c}}$ & $116.8 \pm 9.6$ & $2.7 \pm 0.3^{c}$ & $1326.6 \pm 89.2$ \\
\hline \multirow{5}{*}{$\begin{array}{l}\text { Bentho-pelagic } \\
\text { species }\end{array}$} & $\begin{array}{l}\text { Pinirampus } \\
\text { pirinampu }\end{array}$ & $24.9 \pm 2.5^{\mathrm{b}}$ & $121.3 \pm 10.8$ & $2.5 \pm 0.3^{c}$ & $456.8 \pm 25.0$ \\
\hline & $\begin{array}{l}\text { Pterygoplichthys } \\
\text { pardalis }\end{array}$ & $23.3 \pm 2.1^{b}$ & $128.0 \pm 10.3$ & $1.7 \pm 0.2^{\mathrm{ab}}$ & $214.2 \pm 17.6$ \\
\hline & $\begin{array}{l}\text { Hemisorubim } \\
\text { platyrhynchos }\end{array}$ & $24.3 \pm 1.9^{b}$ & $127.6 \pm 11.0$ & $1.8 \pm 0.2^{\mathrm{ab}}$ & $405.0 \pm 35.9$ \\
\hline & Sorubim lima & $24.5 \pm 2.0^{\mathrm{b}}$ & $145.1 \pm 12.5$ & $1.6 \pm 0.3^{b}$ & $571.7 \pm 35.1$ \\
\hline & $\begin{array}{l}\text { Ageneiosus } \\
\text { ucayalensis }\end{array}$ & $18.4 \pm 1.9^{b}$ & $138.9 \pm 9.7$ & $2.2 \pm 0.2^{\mathrm{a}}$ & $322.3 \pm 20.8$ \\
\hline
\end{tabular}

*Both sides of the gill apparatus 
Table 3. Variations in respiratory area $\left(\mathrm{cm}^{2} \mathrm{~g}^{-1}\right)$ estimated in each gill arch for fish species collected from Lake Janauacá. Different lowercase letters indicate significant differences among the species $(\mathrm{p}<0.05)$ by Kruskal-Wallis nonparametric ANOVA multiple comparisons test

\begin{tabular}{|c|c|c|c|c|c|}
\hline & \multirow[t]{2}{*}{ Species } & \multicolumn{4}{|c|}{ Surface areas, $\mathrm{cm}^{2} \mathrm{~g}^{-1}$ (gill arches) } \\
\hline & & I & II & III & IV \\
\hline \multirow{5}{*}{$\begin{array}{l}\text { Pelagic } \\
\text { fish }\end{array}$} & Pygocentrus nattereri & $1.74 \pm 0.05^{\mathrm{a}}$ & $\begin{array}{c}1.93 \pm \\
0.06^{\mathrm{a}}\end{array}$ & $1.68 \pm 0.04^{\mathrm{a}}$ & $\begin{array}{c}1.14 \pm \\
0.07^{\mathrm{a}}\end{array}$ \\
\hline & Mylossoma duriventre & $0.64 \pm 0.08^{b}$ & $\begin{array}{c}0.71 \pm \\
0.10^{\mathrm{b}}\end{array}$ & $0.69 \pm 0.07^{\mathrm{b}}$ & $\begin{array}{c}0.57 \pm \\
0.05^{\mathrm{b}}\end{array}$ \\
\hline & Psectrogaster rutiloides & $1.24 \pm 0.04^{\mathrm{a}}$ & $\begin{array}{c}1.45 \pm \\
0.05^{\mathrm{a}}\end{array}$ & $1.40 \pm 0.02^{\mathrm{a}}$ & $\begin{array}{c}0.38 \pm \\
0.09^{\mathrm{b}}\end{array}$ \\
\hline & Astronotus ocellatus & $1.01 \pm 0.08^{\mathrm{a}}$ & $\begin{array}{c}1.03 \pm \\
0.05^{\mathrm{a}}\end{array}$ & $1.07 \pm 0.07^{\mathrm{a}}$ & $\begin{array}{c}0.86 \pm \\
0.06^{\mathrm{a}}\end{array}$ \\
\hline & Cichla monoculus & $0.57 \pm 0.09^{\mathrm{b}}$ & $\begin{array}{c}0.62 \pm \\
0.07^{\mathrm{b}}\end{array}$ & $0.61 \pm 0.05^{b}$ & $\begin{array}{c}0.57 \pm \\
0.04^{\mathrm{b}}\end{array}$ \\
\hline \multirow{5}{*}{$\begin{array}{l}\text { Benthic/b } \\
\text { entho-pela } \\
\text { gic fish }\end{array}$} & Pinirampus pirinampu & $0.38 \pm 0.06^{\mathrm{b}}$ & $\begin{array}{c}0.46 \pm \\
0.05^{\mathrm{b}}\end{array}$ & $0.45 \pm 0.05^{\mathrm{b}}$ & $\begin{array}{c}0.37 \pm \\
0.05^{\mathrm{b}}\end{array}$ \\
\hline & Liposarcus pardalis & $0.41 \pm 0.04^{\mathrm{b}}$ & $\begin{array}{c}0.40 \pm \\
0.05^{\mathrm{b}}\end{array}$ & $0.38 \pm 0.06^{\mathrm{b}}$ & $\begin{array}{c}0.41 \pm \\
0.04^{\mathrm{b}}\end{array}$ \\
\hline & $\begin{array}{l}\text { Hemisorubim } \\
\text { platyrhynchos }\end{array}$ & $0.58 \pm 0.04^{\mathrm{b}}$ & $\begin{array}{c}0.62 \pm \\
0.07^{b}\end{array}$ & $0.62 \pm 0.06^{\mathrm{b}}$ & $\begin{array}{c}0.60 \pm \\
0.04^{\mathrm{b}}\end{array}$ \\
\hline & Sorubim lima & $0.47 \pm 0.05^{b}$ & $\begin{array}{c}0.53 \pm \\
0.06^{\mathrm{b}}\end{array}$ & $0.57 \pm 0.04^{b}$ & $\begin{array}{c}0.47 \pm \\
0.05^{\mathrm{b}}\end{array}$ \\
\hline & Ageneiosus ucayalensis & $0.36 \pm 0.05^{\mathrm{b}}$ & $\begin{array}{c}0.37 \pm \\
0.09^{\mathrm{b}}\end{array}$ & $0.34 \pm 0.04^{\mathrm{b}}$ & $\begin{array}{c}0.27 \pm \\
0.06^{\mathrm{b}}\end{array}$ \\
\hline
\end{tabular}

\subsection{Blood Variables}

The hematology was analyzed in the same species studied for RMR and gill morphometry. Similar to gill dimensions, some pelagic species (e.g., $P$. nattereri, $M$. duriventre, $P$. amazonica and $C$. monoculus) have more red blood cells (Fig. 4A), hemoglobin concentration (Fig. 4B) and hematocrit (Fig. 4C) than do benthic fish. The hematological indices (MCV, mean corpuscular volume; $\mathrm{MCH}$, mean corpuscular hemoglobin; and $\mathrm{MCHC}$, mean corpuscular hemoglobin concentration) are shown in Table 4. The highest and lowest values of MCV were observed in A. ocellatus and C. monoculus, respectively. Since MCV is an erythrocyte parameter, it depends on the hematocrit/RBC (red blood cells) ratio. Both 


\section{Macrothink

species had similar values for hematocrit; however, $C$. monoculus presented more circulating red blood cells than A. ocellatus. The values of hematological indices were similar for all studied species.
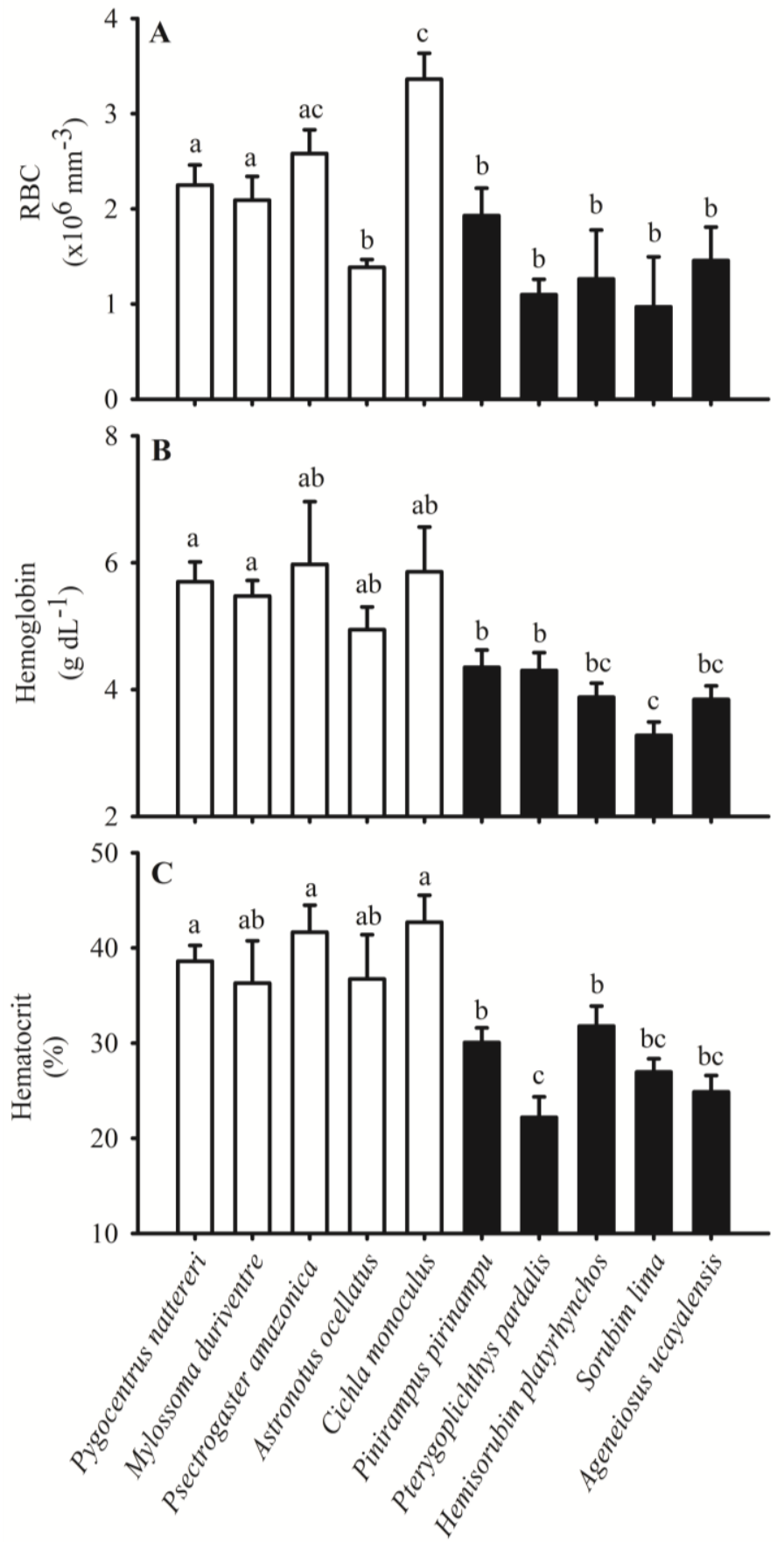

Figure 4. Blood oxygen capacity inferred as red blood cell count, RBC (A), hemoglobin (B) and hematocrit (C) in several fish species from floodplain lakes (Lake Janauacá). The open bars represent the pelagic species, and the filled bars represent the benthic/bentho-pelagic species. Different lowercase letters indicate significant differences among the species ( $\mathrm{p}$ 0.05 ) by Kruskal-Wallis nonparametric ANOVA multiple comparisons test 


\section{Macrothink}

\subsection{Relationship Between Blood Variables, RMR and Gill Dimensions}

Clearly, the two first axes of the principal component analysis (PCA) based on the data matrix of gill morphometrics/oxygen consumption rates $\left(\mathrm{MO}_{2}\right)$ and blood variables were significantly correlated [PC1-gill morphology and $\mathrm{MO}_{2}=-1.49 \times 10^{-6}+(0.539 \mathrm{x}$ PC1-hematological variables), $\mathrm{p}<0.001$, Fig. 5A]. According to our expectation, the mass-specific RMR $\left(\mathrm{MO}_{2}\right)$ was also related to the first axis of PCA based on the matrix of hematological variables [ $\log$ mass-specific $\mathrm{MO}_{2}=1.834+(0.199 \times$ PC1-hematological variables), $\mathrm{p}<0.001$, Fig. 5B]. This relationship was also positive when analyzing the first axis of the PCA data matrix of hematological variables and total gill surface area [gill surface area $=2.676+(0.106 \times$ PC1-haematological variables $), \mathrm{p}<0.001$, Fig. 5C $]$.
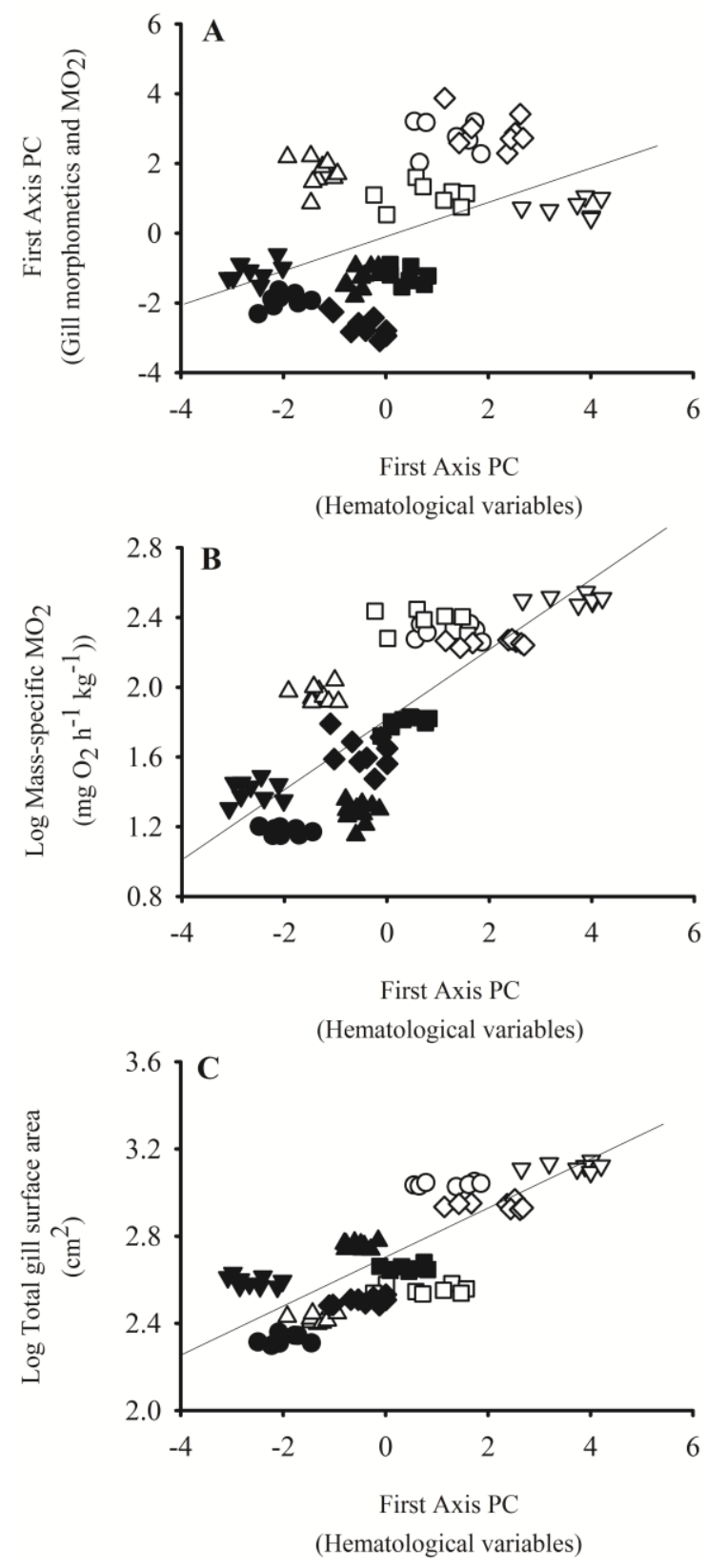

Figure 5. Correlation between the two first axes of PCA based on the data matrix of gill 
morphometrics/routine oxygen consumption rates $\left(\mathrm{MO}_{2}\right)$ and blood variables $(\mathrm{A})$.

Relationship between $\log _{10}$ mass-specific $\mathrm{MO}_{2}$ and first axis of PCA based on the data matrix of hematological variables (B). Correlation between $\log _{10}$ total gill area and first axis of PCA based on the data matrix of hematological variables (C) analyzed in different fish species from Lake Janauacá: Pygocentrus nattereri $(\bigcirc)$, Mylossoma duriventre $(\square)$, Psectrogaster amazonica $(\diamond)$, Astronotus ocellatus $(\triangle)$ and Cichla monoculus $(\nabla)$, Pinirampus pirinampu $(\boldsymbol{\square})$, Pterygoplichthys pardalis $(\mathbf{O})$, Hemisorubim platyrhynchos $(\boldsymbol{\Delta})$, Sorubim lima $(\boldsymbol{\nabla})$ and Ageneiosus ucayalensis $(\diamond)$. The open symbols represent the pelagic species, and the closed symbols represent the benthic/bentho-pelagic species

\section{Discussion}

Several authors have generalized that pelagic fish are more metabolically active than benthic species (De Jager \& Dekkers 1975; Powers 1980; Childress 1995), although it has been speculated that the metabolic demand is adjusted to the oxygen-carrying capacity in the blood. Furthermore, these physiological processes may be closely related to gill morphology. This seems to agree with the concept of symmorphosis already well established in the work of Weibel (2000), in which the structural design of the gills is closely adjusted to the oxygen demand by the animal. Considering these points of view and based on the results obtained in this study, this report discusses the following physiological and ecological issues: (i) are the gill dimensions, RMR and the blood oxygen-carrying capacity adjusted to the metabolic demand of the fish as predicted by the symmorphosis hypothesis? and (ii) are pelagic fish metabolically more active than benthic fish (Killen et al. 2010)?

The gill dimensions, such as the total number and length of filaments, density of lamellae on the filament, blood-water barrier thickness and bilateral surface area of lamellae, are adjusted by selective factors that favor the gill area that meets the oxygen demand of the animal (Hughes et al. 1986; Severi et al. 1997, Wegner et al. 2010). Similarly, blood characteristics, such as the number of circulating red blood cells (RBCs), hematocrit, hemoglobin and RBC indices, reflect the oxygen-carrying capacity (Nikinmaa \& Soivio 2005) and are also adjusted to the metabolic demands of the fish (Powers 1980). Weibel (2000) argues that "the state of structural design commensurate to functional needs resulting from regulated morphogenesis whereby the formation of structural elements is regulated to satisfy but not exceed the requirements of the functional system". In fact, a clear "functional integration" is one of the three principles of the symmorphosis concept originally described by Weibel et al. (1991). Therefore, this study described a morphofunctional integration of gill structure that is matched to environmental oxygen uptake and gas transport through the blood.

As expected, active pelagic predators (e.g., C. monoculus and P. nattereri) have high metabolic rates (320 and $207 \mathrm{mg} \mathrm{O}_{2} \mathrm{~h}^{-1} \mathrm{~kg}^{-1}$, respectively), large mass-specific gill areas (2.3 to $6.7 \mathrm{~cm}^{2} \mathrm{~g}^{-1}$, respectively), densely packed lamellae and a high capacity to carry oxygen in the blood based on hemoglobin concentration, hematocrit and circulating red blood cells. These results are similar to reports for marine teleosts with high energy demands. For example, skipjack tuna (Katsuwonus pelamis Linnaeus, 1758) and yellowfin tuna (Thunnus albacares Bonnaterre, 1788) have high gill areas (18.5 and $13.3 \mathrm{~cm}^{2} \mathrm{~g}^{-1}$, respectively) to meet 
an oxygen uptake of 412 and $286 \mathrm{mg} \mathrm{O}_{2} \mathrm{~h}^{-1} \mathrm{~kg}^{-1}$, respectively, during standard metabolic rates (Muir \& Hughes 1969, Wegner et al. 2010). The Amazon fish do not have high metabolic demands and gill areas, such as those found in high-speed marine scombrids, but the ratio of the routine metabolic rate and gill area of Amazon pelagic fishes appears consistent with the energy requirement. In the Amazon basin, one of the most active fish is the cichlid $C$. monoculus. This species has a relatively large head and caudal fin to quickly accelerate from rest. Furthermore, this fish is able to sprint and perform fast-start maneuvers during predator-prey interactions (Winemiller et al. 1997). P. nattereri is also a highly active predator but is not as fast a swimmer as C. monoculus. However, P. nattereri has a similar metabolic profile to that described for $C$. monoculus. On the other hand, high metabolic demand is not unique in predatory fish. Many pelagic herbivorous, omnivores or detritivorous fish are also metabolically active. For example, $M$. duriventre and $P$. amazonica have values of mass-specific gill area and routine metabolic rate similar to those observed in carnivorous species (Divya \& Ranjeet 2014).

The metabolic level boundaries hypothesis (MBLH) provides a mechanistic link between the lifestyle of organisms and the scaling of metabolism with body size (Glazier 2014). According to the MBLH, species that live in different habitats will have different ecological needs and may affect the metabolic level and, in turn, potentially affect the scaling exponent (Killen et al. 2010). It has been reported that both the scaling exponent and coefficient vary systematically among species (Ohlberger et al. 2012, Huang et al. 2013). This finding explains, at least in part, the differences between predicted and observed and measured values of RMR among the fish species of Lake Janauacá. Pelagic species have a high energy requirement for swimming activity and, in turn, have the highest metabolic level (scaling coefficient). This elevated maintenance cost enhances the role of physical boundary limits, such as gill surface area (Glazier 2014), resulting in a decrease in the values of the scaling exponent (Killen et al. 2010). These authors reported an inverse relationship between metabolic levels and scaling exponent. Thus, benthic fish had the lowest values for metabolic levels and the highest values of the scaling exponent. In the present study, RMR measurements for benthic species suggest that these fish have low metabolic rates. Therefore, it is possible that the value of the scaling exponent in the benthic species can be higher than those found in pelagic fish. Unfortunately, the limited available data are insufficient to calculate a reliable scaling exponent for each species.

In general, larger gill surface areas and thin water-blood barriers are the main factors that increase oxygen uptake capacity (Crampton et al. 2008, Wegner et al. 2010). The oxygen molecules must cross the thin epithelium, which consists of two cell layers. Pavement cells and flanges of pillar cells constitute the water-blood barrier (Evans et al. 2005, Duncan et al. 2010). As chloride cells (or mitochondria-rich cells) are rarely observed on lamellae (except in $C$. monoculus and $M$. duriventre), most species have a thin water-blood barrier varying from 1.2 to $2.7 \mu \mathrm{m}$ (2/3 harmonic mean). Thin barriers tend to improve the morphological potential for gas exchange. However, if the water-blood distance is thick, the oxygen uptake can be compensated by increasing the total gill surface area (Hughes et al. 1986). The anatomical diffusion factor (ADF) is a good measure of this capacity normalized to body 
mass (Hughes, 1984). The ADF for Amazon pelagic fish was $>3 \mathrm{~cm}^{2} \mathrm{~g}^{-1} \mu \mathrm{m}^{-1}$. This value is 3 times greater than those estimated for Atlantic salmon, Salmo salar (Perry 1990). Surprisingly, $C$. monoculus and $M$. duriventre have high routine metabolic rates but demonstrated low ADF values. ADF is a quotient of the mass-specific gill surface area and water-blood barrier. Therefore, the presence of numerous chloride cells in the gill epithelia of these fish species results in an increase in the thickness of the gas exchange barrier. However, the large metabolic rate is compensated by the large gill surface area. Thus, these species maintain osmorespiratory control without altering the delicate balance between gas and ion exchange by the gills.

In general, more than $90 \%$ of the oxygen transported from the gill epithelium is carried by hemoglobin (Nikinmaa \& Soivio 2005). The number of circulating red blood cells, the hemoglobin concentration, the amount of oxygen-binding hemoglobin (modulated by the erythrocyte environment) and the properties of the prevailing oxygen partial pressure all determine the amount of oxygen carried per unit volume of blood (Brunori 2014). Unfortunately, neither the kinetic properties of hemoglobin nor the blood oxygen content were analyzed in this study, but the circulating red cell blood and total hemoglobin content favors species-specific adjustments to carry oxygen, depending on the metabolic demand of each animal.

As previously reported, pelagic predators, such as $C$. monoculus and P. nattereri, have higher hematocrit values, hemoglobin contents and circulating red blood cell levels compared with benthic fish. In contrast, fish that live in benthic environments have large cell volumes. It is possible that cell volume may influence hemoglobin-oxygen affinity (Brunori 2014). As the bottom environment in floodplain lakes is usually hypoxic or anoxic (Anjos et al. 2008), it is possible that a higher cell volume may be advantageous for benthic fish. Wells (2009) suggested that fish with an active swimmer lifestyle tend to have a high $\mathrm{O}_{2}$-carrying capacity and a relatively low oxygen affinity, and the blood $\mathrm{Hb}-\mathrm{O}_{2}$ affinity is modulated by ATP. On the other hand, fish that live in habitats that have periodically low dissolved oxygen concentrations (hypoxic) may also have high oxygen-carrying capacities, but generally, these species have high blood hemoglobin $\mathrm{O}_{2}$ affinities, and the affinity is modulated by GTP or ATP (Val \& Almeida-Val 1995).

In the Amazon basin, several fish species have developed adaptations to tolerate hypoxia and, occasionally, anoxia. Moreover, some species are more tolerant than others. For example, $A$. ocellatus is highly anoxia-resistant and can survive in severe hypoxia for 20 hours and anoxia for up to 6 hours (Muusze et al. 1998; Almeida-Val et al. 2000). Metabolic arrest and/or activation of anaerobic metabolism have been described as the main strategy for this cichlid to survive in severe hypoxic and anoxic conditions (Almeida-Val et al. 2000; Chippari-Gomes et al. 2005, Scott et al. 2008). Although A. ocellatus is closely related to $C$. monoculus, this species has only one-third of the mass-specific RMR estimated for $C$. monoculus. However, A. ocellatus has a thin water-blood barrier that can facilitate gas transport through the gill epithelium. The catfish P. pardalis also has a low RMR, but this catfish is a facultative air-breathing species (Val \& Almeida-Val 1995). It is important to emphasize that in the study of this species, the fish were not given access to atmospheric 
oxygen. This loricariid occupies most hypoxia-prone habitats in the Neotropical region, and $P$. paradalis is one of 673 loricariid species that use the stomach for air breathing (Nelson \& Dehn 2011).

In summary, pelagic $P$. nattereri, $M$. duriventre, $P$. amazonica and $C$. monoculus have higher metabolic rates, large gill surface areas and high capacities for carrying oxygen through the blood compared to benthic species. The blood characteristics, such as the number of circulating red blood cells, hemoglobin, hematocrit and RBC indices, are correlated with RMR and gill dimensions (surface area, lamellar area and anatomical diffusion factor). This study can help researchers understand the complex relationships between pelagic and benthic fish communities in an Amazon floodplain lake in relation to their physiological ecology. However, more studies are needed to establish further generalizations.

\section{Acknowledgments}

This study was supported by "Ciências Pesqueiras nos Trópicos" postgraduate program (CIPET/UFAM). The author is indebted to Guilherme M. Freire, Yago V.S. Santos, Eliza M.C. Sena, Rubia N. Machado, Regiane M. Linhares and Erica M. Vale for their assistance during both the field and lab work.

\section{References}

Almeida-Val, V. M. F., Val, A. L., Duncan, W. P., Souza, F. C. A., Paula-Silva, M. N., \& Land, S. (2000). Scaling effects on hypoxia tolerance in the Amazon fish Astronotus ocellatus (Perciformes: Cichlidae): contribution of tissue enzyme levels. Comparative Biochemistry and Physiology B, 125, 219-226. https://doi.org/10.1016/S0305-0491(99)00172-8

Anjos, M. B., Oliveira, R. R., \& Zuanon, J. B. (2008). Hypoxic environments as refuge against predatory fish in the Amazonian floodplains. Brazilian Journal of Biology, 68, 45-50. https://doi.org/10.1590/S1519-69842008000100007

Brunori, M. (2014). Variation of the theme: allosteric control in hemoglobin. FESBS Journal 281, 633-643. https://doi.org/10.1111/febs. 12586

Campos, D. F., Jesus, T. F., Kochhann, D., Heinrichs-Caldas, W., Coelho, M. M., \& Almeida-Val, V. M. F. (2017). Metabolic rate and thermal tolerance in two congeneric Amazon fishes: Paracheirodon axelrodi Schultz, 1956 and Paracheirodon simulans Géry, 1963 (Characidae). Hydrobiologia, 789, 133-142. https://doi.org/10.1007/s10750-016-2649-2

Childress, J. J. (1995). Are there physiological and biochemical adaptations of metabolism in deep-sea animals? Trends in Ecology \& Evolution, 10, 30-36.

https://doi.org/10.1016/S0169-5347(00)88957-0

Chippari-Gomes, A. R., Gomes, L. C., Lopes, N. P., Val, A. L., \& Almeida-Val, V. M. F. (2005). Metabolic adjustments in two Amazonian cichlids exposed to hypoxia and anoxia. Comparative Biochemistry and Physiology B, 141, 347-355. https://doi.org/10.1016/j.cbpc.2005.04.006

Crampton, W. G. R., Chapman, L. J., \& Bell, J. (2008). Interspecific variation in gill size is 
correlated to ambient dissolved oxygen in the Amazonian electric fish Brachyhypopomus (Gymnotiformes: Hypopomidae). Environmental Biology of Fishes, 83, 223-235. https://doi.org/10.1007/s10641-007-9325-3

De Boeck, G., Wood, C. M., Ifitkar, F. I., Matey, V., Scott, G. R., Sloman, K. A., Paula-Silva, M. N., \& Almeida-Val, V. M. F. (2013). Interaction between hypoxia tolerance and food deprivation in Amazonian oscars, Astronotus ocellatus. The Journal of Experimental Biology, 216, 4590-4600. https://doi.org/10.1242/jeb.082891

De Jager, S., \& Dekkers, W. J. (1975). Relation between gill structure and activity in fish. Netherlands Journal of Zoology, 25, 276-308. https://doi.org/10.1163/002829675X00290

Divya, P. K., \& Ranjeetm, K. (2014). Effect of temperature on oxygen consumption and ammonia excretion in red bellied piranha Pygoncenthrus nattereri Kner, 1858. Journal of aquatic biology, 2, 97-104

Duncan, W. P., Costa, O. T. F., Sakuragui, M. M., \& Fernandes, M. N. (2010). Functional morphology of the gill in Amazonian freshwater stingrays (Chondrichthyes: Potamotrygonidae): implications for adaptation to freshwater. Physiological and Biochemical Zoology, 83, 19-32. https://doi.org/10.1086/605458

Evans, D. H., Piermarini, P. M., \& Choe, K. P. (2005). The multifunctional fish gill: dominant site of gas exchange, osmoregulation, acid-base regulation, and excretion of nitrogenous waste. Physiological Reviews, 85, 97-177. https://doi.org/10.1152/physrev.00050.2003

Glazier, D. S. (2014). Scaling of metabolic scaling with physical limits. Systems, 2, 425-450. https://doi.org/10.3390/systems2040425

Huang, Q., Zhang, Y., Liu S., Wang, W., \& Luo, Y. (2013). Intraspecific scaling of the resting and maximum metabolic rates of the crucian carp (Carassius auratus). PLoS ONE, 8, e82837. https://doi.org/10.1371/journal.pone.0082837

Hughes, G. M. (1972). Morphometrics of fish gills. Respiration Physiology, 14, 1-25. https://doi.org/10.1016/0034-5687(72)90014-X

Hughes, G. M. (1984). General anatomy of the gills. In Hoar, W. S. \& D. J. Randall (eds), Fish physiology, Vol. 10. Academic Press, Orlando, FL: 1-72. https://doi.org/10.1016/S1546-5098(08)60317-9

Hughes, G. M., \& Morgan, M. (1973). The structure of fish gills in relation to their $\begin{array}{llll}\text { respiratory function. } & \text { Biological } & \text { Reviews, } & 48,\end{array}$ https://doi.org/10.1111/j.1469-185X.1973.tb01009.x

Hughes, G. M., Perry, S. F., \& Piiper, J. (1986). Morphometry of the gills of the elasmobranch Scyliorhinus stellaris in relation to body size. The Journal of Experimental Biology, 121, 27-42.

Jonhston, I. A., Camm, J. P., \& White, M. (1988). Specialisations of swimming muscles in the pelagic antartic fish Pleuragramma antacticum. Marine Biology, 100, 3-12. 
https://doi.org/10.1007/BF00392949

Killen, S. S., Atkinson, D., \& Glazier, D. S. (2010). The intraspecific scaling of metabolic rate with body mass in fish depends on lifestyle and temperature. Ecology Letters, 13, 184-193. https://doi.org/10.1111/j.1461-0248.2009.01415.x

Matey, V., Iftikar, F. I., De Boeck, G., Scott, G. R., Sloman, K. A., Almeida-Val, V. M. F., Val A. L., \& Wood, C. M. (2011). Gill morphology and acute hypoxia: responses of mitochondria-rich, pavement, and mucous cells in the Amazonian oscar (Astronotus ocellatus) and rainbow trout (Oncorhynchus mykiss), two species with very different approaches to the osmo-respiratory compromise. Canadian Journal of Zoology, 89, 307-324. https://doi.org/10.1139/z11-002

Muir, B. S., \& Hughes, G. M. (1969). Gill dimensions for three species of tunny. The Journal of Experimental Biology, 51, 271-285. https://doi.org/10.2307/1441949

Muusze, B., Marcon, J., van der Thillart, G., \& Almeida-Val, V. M. F. (1998). Hypoxia tolerance of Amazon fish: respiratory and energy metabolism of the cichlid Astronotus ocellatus, Comparative Biochemistry and Physiology A, 120, 151-156. https://doi.org/10.1016/S1095-6433(98)10023-5

Nelson, J. A., \& Dehn, A. M. (2011). Morphological diversity of the gastrointestinal tract in fish. In M. Grossel, A. P. Farrel, \& C. J. Brauner (Eds), The multifunctional gut of fish, Fish Physiology (pp. 395-433). San Diego: https://doi.org/10.1016/S1546-5098(10)03010-4

Nikinmaa, M., \& A. Soivio (2005). Blood oxygen transport of hypoxia Salmo gairdneri. Journal of Experimental Zoology, 219, 173-178. https://doi.org/10.1002/jez.1402190206

Nilsson, G. E. \& Östlund-Nilsson, S. (2008). Does size matter for hypoxia tolerance in fish? Biological Reviews, 83, 173-189. https://doi.org/10.1111/j.1469-185X.2008.00038.x

Ohlberger, J., Mehner, T., Staaks, G., \& Hölker, F. (2012). Intraspecific temperature dependence of the scaling of metabolic rate with body mass in fishes and its ecological implications. Oikos, 121, 245-251. https://doi.org/10.1111/j.1600-0706.2011.19882.x

Ong, K. J., Stevens, E. D., \& Wright, P. A. (2007). Gill morphology of the mangrove (kryptolebias marmoratus) is plastic and changes in response to terrestrial air exposure. $J$. Journal of Experimental Zoology, 210, 1109-1115. https://doi.org/10.1242/jeb.002238

Pauly, D. (1981). The relationships between gill surface area and growth performance in fish: a generatization of von Bertalanffy's theory of growth. Berichte der Deustschen Wissenchaftlichen Kommission für Meeresforschung, 28, 251-282.

Perry, S. F. (1990). Recent advances and trends in the comparative morphometry of vertebrate gas exchange organs. In: Advances in R. G. Boutilier (Ed.), Comparative and Environmental Physiology. Vertebrate Gas: Exchange from Environment to Cell (pp. 43-71). New York: Springer-Verlag. https://doi.org/10.1007/978-3-642-75380-0_3 
Powers, D. A. (1980). Molecular ecology of teleost fish hemoglobins: strategies for adapting to changing environments. American Zoologist, 20, 139-162. https://doi.org/10.1093/icb/20.1.139

Roberts, J. L. (1975). Active branchial and ram gill ventilation in fish. Biol. Bull. 148, 85-105. https://doi.org/10.2307/1540652

Rogers, N. J., Urbina, M. A., Reardon, E. E., McKenzie, D. J., \& Wilson, R.W. (2016). A new analysis of hypoxia tolerance in fishes using a database of critical oxygen level ( $\left.P_{\text {crit }}\right)$. Conservation Physiology, 4. https://doi.org/10.1093/conphys/cow012

Rombough, P. J., \& Moroz, B. M. (1997). The scaling and potential importance of cutaneous and branchial surface in respiratory gas exchange in larval and juvenile walleye Stizostedion vitreum. Journal of Experimental Zoology, 200, 2459-2468.

Saint-Paul, U. (1983). Investigation on the respiration of the Neotropical fish, Colossoma macropomum (Serrasalmidae). The influence of weight and temperature on the routine oxygen consumption. Amazoniana, VII, 433-443.

Saint-Paul, U. (1984). Physiological adaptation to hypoxia of a neotropical characoid fish Colossoma macropomum, Serrasalmidae. Environmental Biology of Fishes, 11, 53-62. https://doi.org/10.1007/BF00001845

Saint-Paul, U., \& Soares, M. G. M. (1987). Diurnal distribution and behavioral responses of fishes to extreme hypoxia in an Amazon floodplain lake. Environmental Biology of Fishes, 20, 91-104. https://doi.org/10.1007/BF00005289

Scott, G. R., Wood C. M., Sloman, K. A., Iftikar, F. I., De Boeck, G., Almeida-Val, V. M. F., \& Val A. L. (2008). Respiratory response to progressive hypoxia in the Amazonian oscar, Astronotus ocellatus. Environmental Biology of Fishes, 162, 109-116. https://doi.org/10.1016/j.resp.2008.05.001

Severi, W., Rantin, F. T., \& Fernandes, M. N. (1997). Respiratory gill surface of the serrasalmid fish, Piaractus mesopotamicus. Journal of Fish Biology, 50, 127-136. https://doi.org/10.1111/j.1095-8649.1997.tb01345.x

Val, A. L. \& Almeida-Val, V. M. F. (1995). Fishes of the Amazon and their environments. Physiological and Biochemical features. Heidelberg: Springer Verlag. https://doi.org/10.1007/978-3-642-79229-8

Wegner, N. C., Sepulveda, C. A., Bull, K. B., \& Graham, J. B. (2010). Gill morphometrics in relation to gas transfer and ram ventilation in high-energy demand teleosts: Scombrids and Billfishes. Journal of Morphology, 271, 36-49. https://doi.org/10.1002/jmor.10777

Weibel, E. R. (2000). Symmorphosis. On form and function in shaping life. Harvard Massachusetts: University Press.

Weibel, E. R., Taylor, C. R., \& Hoppeler, H. (1991). The concept of symmorphosis: a testable hypothesis of structure-function relationship. Proceedings of the National Academy of 


\section{Macrothink}

Aquatic Science and Technology

ISSN 2168-9148 2020, Vol. 8, No. 1

Sciences of the United States of America, 88, 10357-10361. https://doi.org/10.1073/pnas.88.22.10357

Wells, M. G. (2009). Blood-gas transport and hemoglobin function: adaptations for functional and environmental hypoxia. In I. G. Richards, A. P. Farrell, \& C. J. Brauner (Eds.), Hypoxia. Fish Physiology (pp. 255-299. San Diego: Academic Press. https://doi.org/10.1016/S1546-5098(08)00006-X

Winemiller, K. O., Taphorn, D. C., \& Barbarino-Duque, A. (1997). The ecology of Cichla (Cichlidae) in two blackwater rivers of southern Venezuela. Copeia, 4, 690-696. https://doi.org/10.2307/1447287

\section{Copyrights}

Copyright for this article is retained by the author(s), with first publication rights granted to the journal.

This is an open-access article distributed under the terms and conditions of the Creative Commons Attribution license (http://creativecommons.org/licenses/by/4.0/) 